\title{
Daylength, temperature and fertilization effects on desiccation resistance, cold hardiness and root growth potential of Picea mariana seedlings
}

\author{
Stephen J. ColOMBO ${ }^{\mathrm{a} *}$, Chris GleRum ${ }^{\mathrm{a} \uparrow}$ and D. Paul $\mathrm{WeBB}^{\mathrm{b}}$ \\ ${ }^{\text {a }}$ Ontario Forest Research Institute, Ontario Ministry of Natural Resources, 1235 Queen Street, Sault Ste. Marie, Ontario P6A 2E5, Canada \\ ${ }^{\mathrm{b}}$ Great Lakes Forestry Centre, Canadian Forest Service, Sault Ste. Marie, Ontario, Canada
}

(Received 17 January 2002; accepted 19 August 2002)

\begin{abstract}
Picea mariana (Mill.) B.S.P. seedlings were hardened for overwintering under four regimes. In three regimes, seedlings were kept inside a heated greenhouse for 11 weeks during and after dormancy induction (August to mid-November), with either 1 . Natural daylengths $\left(46^{\circ} 31^{\prime} \mathrm{N}\right)$ and warm temperatures of $20^{\circ} \mathrm{C}$ or more (NDW), 2. As 1, but fertilized (NDWF) or 3. As 1, but with shortened daylengths (SD). In the fourth regime (OD), seedlings were hardened outside at naturally declining temperatures and daylengths without fertilizer. Seedlings hardened in any warm temperature treatment had buds with more needle primordia and shoots more resistant to desiccation than OD seedlings. Initially, cold hardiness tended to be greatest in SD seedlings. As hardening progressed OD seedlings became equally cold hardy to SD. In late November when all trees were outside, NDW seedlings were usually least cold hardy. Spring root growth potential was least in OD seedlings.
\end{abstract}

cold hardiness / desiccation / needle primordia / transpiration / water potential

Résumé - Effets de la longueur du jour, de la température et de la fertilisation sur la résistance à la dessiccation et au froid, et au potentiel de croissance de plants de Picea mariana. On a soumis des semis de Picea mariana (Mill.) à quatre traitements pour les endurcir au froid en vue de la période hivernale. Pour trois traitements les plants ont été installés sous serre chauffée pendant 11 semaines, pendant et après l'induction de la dormance, avec les 3 modalités suivantes : (1) longueur naturelle du jour (latitude $46^{\circ} 31^{\prime} \mathrm{N}$ ) et chauffage à une température égale ou supérieure à $20^{\circ} \mathrm{C}(\mathrm{NDW}) ;(2)$ comme le traitement 1 , mais avec fertilisation (NDWF); (3) comme le traitement 1 mais en jours courts $(\mathrm{SD})$. Pour le quatrième traitement (OD) les plants ont été endurcis à l'extérieur avec la baisse de température et la diminution de la longueur des jours des conditions naturelles, sans faire appel à une fertilisation. Les plants issus des traitements comportant une phase sous serre chaude présentaient des bourgeons ayant davantage d'ébauches foliaires et des pousses plus résistantes à la dessication que les plants du traitement OD. Dans un premier stade, l'endurcissement au froid des plants SD tendait à être plus élevé. Ultérieurement celui des plants OD est devenu équivalent à celui des SD. Fin novembre, tous les plants étaient à l'extérieur, les plants NDW étaient moins résistants au froid. Le potentiel de croissance racinaire au printemps était moins élevé pour les plants OD.

endurcissement pour la résistance au froid / dessication / ébauche racinaire / transpiration / potentiel hydrique

\section{INTRODUCTION}

A series of morphological and physiological changes occur during dormancy enabling trees to survive stresses during the winter [19]. In seedlings of many tree genera, including Picea, these changes are initiated largely in response to short photoperiods [5] and entail the cessation of shoot elongation, initiation of terminal buds, stem lignification, and increased cold hardiness. Other morphological changes also occur in the shoots at this time that increase the ability of seedlings to avoid water loss, such as needle cuticle thickening and wax deposition $[17,37,38]$.
Freezing and desiccation are related stresses affecting trees in winter. Extracellular freezing is a cause of desiccation as water moves along a gradient in water potential to sites outside the cells where ice crystals first form [16, 21, 32]. Freezing is, therefore, a form of drought stress because of the compartmentalization of water outside the cells, although it causes no net change in tissue water content. The resulting concentrating effect on cell electrolytes is thought to aid survival by reducing the risk of intracellular freezing, owing to the lowering of the cytoplasm freezing point [32, 34].

Moisture deficits increase further when the cellular desiccation brought about by extracellular freezing is compounded by

\footnotetext{
* Correspondence and reprints

Tel.: 705946 7409; fax: 705946 2030; e-mail: steve.colombo@mnr.gov.on.ca

$\dagger$ Deceased.
} 
tissue desiccation when water is lost to the atmosphere. Shoots desiccate in winter when they are exposed to the air and translocation is blocked by the soil and/or stem being frozen and the xylem cavitated $[27,37]$. Very low water potentials have been recorded during the winter in trees growing at alpine timberlines where cold temperatures often occur without a protective covering of snow $[22,23]$. Whether trees in non-alpine environments also reach potentially damaging water potentials in winter is less well known. The protection provided by an insulating blanket of snow in winter reduces desiccation and protects shoots and roots from freezing [25]. However, seedlings are prone to desiccation and freezing damage in the fall before snow completely covers them, during periods of winter thaw if the snow cover is temporarily lost, or in the spring after the snow cover melts.

Winter damage due to freezing (and presumably desiccation) is a natural event in forests shaping the distribution of species and the genetic properties of tree populations [1, 2, $31]$. In tree nurseries the goal is to avoid damage and produce seedlings possessing high growth potential for planting. Knowledge of how desiccation resistance and cold hardening are affected by the environment during hardening is still incomplete and in some cases the published information is contradictory. This study describes the effect of temperature, fertilizer application, and daylength on the development of needle primordia in buds, desiccation resistance, cold hardiness, and root growth potential of black spruce seedlings (Picea mariana (Mill.) B.S.P.).

\section{MATERIALS AND METHODS}

\subsection{Cultural practices}

Black spruce seeds from a northeastern Ontario seed source (approximate origin $48^{\circ} \mathrm{N}, 81^{\circ} \mathrm{W}$ ) were sown in May 1982, on a peat moss/vermiculite medium in Japanese FH $408\left(70 \mathrm{~cm}^{3}\right)$ Paperpot ${ }^{\circledR}$ containers. Seedlings were grown inside a heated greenhouse at the Swastika Tree Nursery $\left(48^{\circ} 06^{\prime} \mathrm{N}, 80^{\circ} 06^{\prime} \mathrm{W}\right)$ using a standard operational cultural regime that included natural daylengths and periodic fertilization with a NPK soluble fertilizer. On August 2, 60 trays containing approximately 18000 seedlings were transported to a greenhouse in Sault Ste. Marie, Ontario ( $46^{\circ} 31^{\prime}$ N, $84^{\circ} 20^{\prime}$ W). Fifteen trays containing a total of about 4500,12 -week-old seedlings were assigned to each of four hardening treatments:

(1) Outdoors (OD)

On August 3 (week 0 of the experiment), the trays were watered with approximately two times the volume of the container to leach fertilizer from the growing medium. The seedlings were then moved outside and placed on raised pallets. After placement outside seedlings experienced natural daylengths and full sunlight and were not fertilized. On November 4 the trays were taken off the raised pallets and placed directly on the ground. Average maximum, average minimum, and monthly lowest air temperatures recorded by the Atmospheric Environment Service of Environment Canada (Sault Ste. Marie station "A") were $20.1^{\circ} \mathrm{C} / 9.8^{\circ} \mathrm{C} / 1.7^{\circ} \mathrm{C}$ in August, $17.4{ }^{\circ} \mathrm{C} / 8.7{ }^{\circ} \mathrm{C} / 2.6{ }^{\circ} \mathrm{C}$ in September, $12.8{ }^{\circ} \mathrm{C} / 4.1{ }^{\circ} \mathrm{C} /-3.0^{\circ} \mathrm{C}$ in October and $4.7^{\circ} \mathrm{C} /-2.2{ }^{\circ} \mathrm{C} /-10.2^{\circ} \mathrm{C}$ in November.

(2) Natural Daylengths + warm temperatures (NDW)

These seedlings were treated similarly to OD seedlings but were kept inside a fibreglass-covered greenhouse heated to maintain minimum temperatures at $20^{\circ} \mathrm{C}$; day temperatures never exceeded $28^{\circ} \mathrm{C}$. Light intensity inside the greenhouse was approximately $50 \%$ of full sunlight. On November 4 (11 weeks from the beginning of the hardening treatments), trays were removed from the greenhouse and placed on the ground alongside OD seedlings where they were exposed to ambient temperatures outside.

(3) Natural daylengths + warm temperatures + fertilizer (NDWF) Seedlings were treated the same as NDW seedlings (i.e., natural daylengths inside the heated greenhouse until November 4) but while in the greenhouse were watered weekly to saturation with a solution of a 20-20-20 (NPK) commercial fertilizer (without micronutrients) at a concentration of $150 \mathrm{ppm}$ nitrogen.

(4) Short daylengths (SD)

Short day seedlings were hardened similarly to NDW seedlings (i.e., no fertilizer and the trees kept inside the heated greenhouse until November 4) but were exposed to $8 \mathrm{~h}$ days until moved outside on November 4 . The shortened daylength treatment was applied by suspending an opaque black plastic sheet over and around the sides of trays of seedlings from $1600 \mathrm{~h}$ of each weekday, Monday to Thursday, to $0800 \mathrm{~h}$ the following morning. Seedlings experienced natural daylengths between Friday afternoon and Monday morning of each week and on September 6 and October 11.

Container growing medium moisture contents were maintained near field capacity in all treatments. When applying fertilizer similar amounts of water without fertilizer were applied to the other treatments.

\subsection{Sampling and measurements}

Fifteen trays of seedlings were assigned to each treatment at the beginning of the experiment. For practical reasons, treatments were not subdivided into replicates in the greenhouse or the holding area. Shoot elongation, main stem terminal bud budscale initiation and number of needle primordia, cold hardiness, shoot tip transpiration, and shoot xylem pressure potential were assessed periodically from the start of the hardening treatments until late November. Root growth potential was assessed about monthly from November 11 to March 25.

The methods described in Templeton et al. [35] were used to assess main stem terminal bud budscale initiation (i.e., dormancy induction) and to count needle primordia in the buds of 13 to 30 randomly selected seedlings (averaging 20) per treatment each week. Weekly height growth was assessed on a permanent sample of 19 or 20 seedlings remeasured weekly. Height, diameter and shoot dry weight were measured on 50 seedlings collected from each treatment 14 weeks after hardening began.

Cold hardiness was determined weekly using 5 replicates of 3 randomly selected main stem shoot tips per hardening treatment (OD, NDW, NDWF and SD) and temperature $\left(-10^{\circ} \mathrm{C}\right.$ from week 1 to 12 and $-17{ }^{\circ} \mathrm{C}$ from week 8 to 14 ). Each shoot tip was from a different seedling. Cold hardiness was evaluated using a modified electrolyte leakage technique [14]. Prior to freezing, each replicate was immersed in $30 \mathrm{~mL}$ distilled water in a test tube. After about $24 \mathrm{~h}$ at room temperature the water was decanted and the test tubes containing shoots were immersed in a methanol bath; bath temperature decreased from +5 to $-10^{\circ} \mathrm{C}$ over 70 min and test tubes were removed from the bath $30 \mathrm{~min}$ after reaching the minimum temperature. For freezing to $-17^{\circ} \mathrm{C}$ the bath temperature decreased from $+5{ }^{\circ} \mathrm{C}$ to $-12{ }^{\circ} \mathrm{C}$ over the first hour and from $-12{ }^{\circ} \mathrm{C}$ to $-17{ }^{\circ} \mathrm{C}$ over the ensuing $90 \mathrm{~min}$. The test tubes were removed from the bath after $30 \mathrm{~min}$ at $-17^{\circ} \mathrm{C}$. Rates of freezing are usually kept at or below $6{ }^{\circ} \mathrm{C}$ per hour to avoid intracellular freezing. However, according to Sutinen et al. [34], freezing rates faster than those used here do not necessarily result in intracellular freezing. Nevertheless, the absolute levels of tissue damage we report should be compared with care to those of studies where slower freezing rates were employed. There is 
no evidence we are aware of suggesting that relative differences in cold hardiness between treatments within an experiment would be affected by freezing rate.

After freezing, the test tubes were removed from the bath and placed at $+5{ }^{\circ} \mathrm{C}$ overnight to thaw. The decanted water, whose prefreezing electrical conductivity had been measured using a Radiometer model CDM83 conductivity meter, was returned to the test tubes the morning after freezing. After $24 \mathrm{~h}$ at room temperature the post-freezing solution electrical conductivity was measured and the test tubes, containing water and shoots, were placed in boiling water for $10 \mathrm{~min}$ to kill the shoots. Following a final $24 \mathrm{~h}$ at room temperature, a final, "killed" solution electrical conductivity was measured. Cold hardiness was expressed as an index of injury [18], where the elevated conductivity caused by the leaching of electrolytes from the shoots into solution before and after freezing is expressed relative to the total electrolyte content after killing the tissues.

Transpiration was measured for 10 weeks beginning the fourth week after the start of the hardening treatments. For brevity, data is provided for only every other week. For each date and hardening treatment, 12 randomly sampled shoot tips were excised before dawn, $3 \mathrm{~cm}$ below the apical meristem. The shoot tips were grouped into 4 replicates of 3 shoot tips. Each replicate was placed into a weighing tray, weighed, and put in a controlled environment chamber at $22^{\circ} \mathrm{C}$, $200-220 \mu \mathrm{E} \mathrm{m}^{-2} \mathrm{~s}^{-1}$ and $70-80 \%$ relative humidity. After six hours the weight of the shoot tips was remeasured and shoot tip volume per replicate then measured by water volume displacement. Transpiration was equated to water loss from the shoots tips (mg water lost $\mathrm{mL}^{-1}$ shoot tip volume). Water loss was due to both stomatal and cuticular transpiration from the needles and, to a much smaller extent, from the shoot periderm. Because the shoot tips were not rehydrated prior to measuring transpiration, the values reflect both the moisture status at the time of collection and the resistance to water loss from the shoots.

Shoot xylem pressure potentials were measured on October 14, November 2, 3, 7, 10, 16 and 23. On each of these dates xylem pressure potential was measured about every $2 \mathrm{~h}$ beginning before dawn until dusk using a pressure chamber and excised shoots from 10 randomly selected seedlings per treatment. Predawn values are shown for all dates and the full daily set of readings only for November 3,10,16 and 23. Shoots sampled outside were placed into plastic bags lined with damp paper towel and allowed to equilibrate to room temperature before measurement.

To determine root growth potential (RGP), one tray of seedlings per treatment was collected from the overwintering area on November 11, December 17, January 14, February 17 and March 25. Trays were thawed in the dark at room temperature for about 48 hours sealed in plastic bags before being placed in a greenhouse $\left(20^{\circ} \mathrm{C}\right.$ to $26^{\circ} \mathrm{C}$ and daylength extended to $16 \mathrm{~h}$ using mercury vapour lamps). After three weeks, the number of white roots $1 \mathrm{~cm}$ or more in length was counted on up to 50 randomly selected seedlings per treatment. As winter progressed the amount of damage to seedlings increased and, because foliar damage reduces RGP [13], an average RGP was estimated using seedlings with no more than $25 \%$ of the needles damaged.

\subsection{Statistical analysis}

Data analysis was done using SigmaStat software (SPSS Inc., Chicago, IL). For each attribute (weekly height growth, final shoot lengths, diameters, and dry weights, cold hardiness, transpiration, shoot xylem pressure potential, and root growth potential) a one-way analysis of variance was performed to compare hardening regimes on each measurement date. Hardening regime was the main-effects component tested in each ANOVA model. In the analyses of variance, each seedling was considered a replicate for measurements of height growth $(n=20)$, shoot length $(n=50)$, diameter $(n=50)$, dry weight $(n=50)$, shoot xylem pressure potential $(n=10)$, and root growth potential ( $n=16$ to 50$)$. In the analysis of transpiration data, there were 3 replications of each hardening regime with a separate ANOVA for every date of measurement. For cold hardiness data, a separate ANOVA was done for each test date and freezing temperature. Each cold hardiness ANOVA had 5 replications per hardening regime. For all attributes, significant differences between hardening regimes on each date were assessed using Fisher's protected LSD test $(P \leq 0.05)$ only if the $P$ value for treatment effects in the ANOVA was $\leq 0.05$ and the assumptions of normality and equal variance were met $(P \geq 0.025)$. Only in the case of needle primordia (on weeks $4,7,8,9$ and the final number calculated from primordia on weeks 12-14) and weekly height growth could the assumptions of normality and equal variance not be satisfied by applying an appropriate transformation of the data. In these cases, a Kruskal-Wallis one way ANOVA on ranks was carried out. Where the ANOVA on ranks was significant $(P \leq$ $0.05)$, this was followed by Student-Newman-Keuls all-pairwise multiple comparison procedure, or, where sample size was unequal, Dunn's test.

\section{RESULTS}

\subsection{Budscale initiation, needle primordia development, height growth and morphology}

Seedlings treated with $8 \mathrm{~h}$ daylengths were the first to initiate budscales at the apical shoot meristem. About $94 \%$ of SD seedlings initiated terminal buds after 2 weeks of treatment and $100 \%$ initiated terminal buds within 3 weeks. In contrast, $60-70 \%$ of the seedlings in the other treatments initiated terminal buds after 3 weeks, reaching $100 \%$ by the fourth week. Height growth continued in all but the OD treatment for 4 weeks after the start of hardening, but seedlings receiving fertilizer usually grew significantly more in height than seedlings from other treatments (Fig. 1). The ANOVA $P$-values for height growth were $<0.001$ for week $1,0.006$ for week 2 and $>0.05$ on weeks 3,4 and 5.

After 14 weeks of hardening the SD treatment produced seedlings with smaller average diameter than NDW and NDWF seedlings. In addition, OD seedlings were significantly shorter at the end of the experiment than those in other treatments, NDWF seedlings had greater diameter and height than OD and SD seedlings, and NDW seedlings had the greatest shoot dry weight (Tab. I).

Most of the final number of needle primordia were accrued in terminal buds of OD, NDW and SD seedlings within 7 weeks of the start of hardening, while with fertilization additional primordia initiated slowly for several more weeks (Fig. 2). Apparent decreases in needle primordia over time reflect sampling variation, since a new set of buds was dissected on each date. In the first 6 weeks of hardening the only significant differences between treatments were on week 2, when SD seedlings had more needle primordia than OD and NDWF seedlings, and on week 3 when SD had more primordia than all other treatments. From the ninth week on, fertilized seedlings had significantly more needle primordia compared with seedlings of all other treatments. After needle primordia initiation in terminal buds was complete, NDWF 


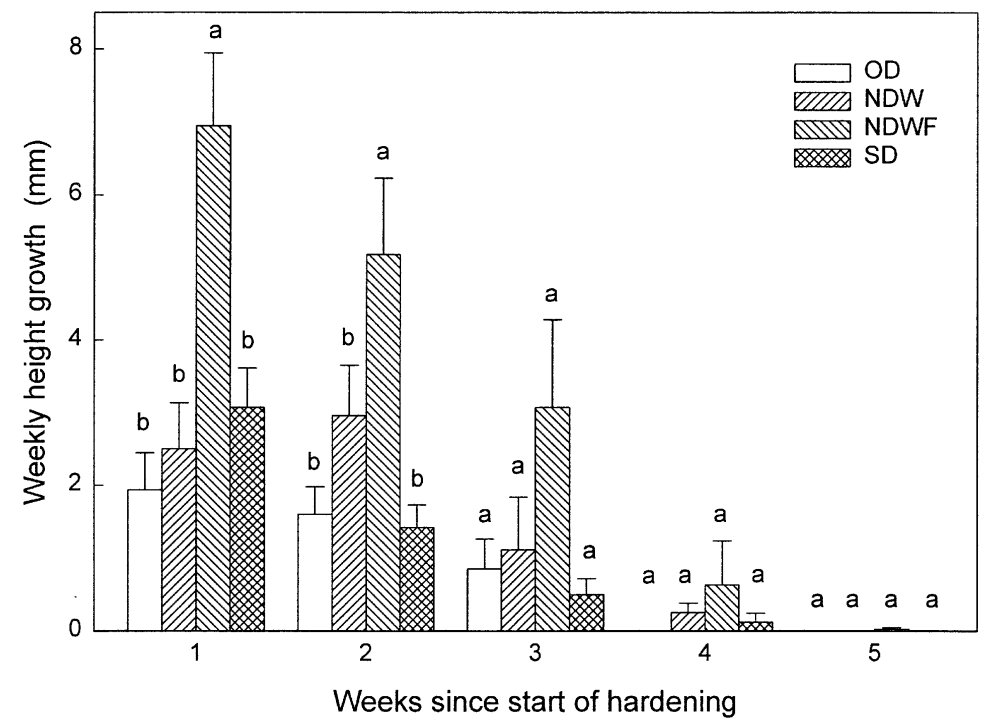

Figure 1. Height growth (and standard error bars) of black spruce seedlings from four hardening regimes $(n=20)$. Within any week bars with differing letters differ significantly according to Kruskal-Wallis one way ANOVA on ranks and Student-Newman-Keuls all-pairwise multiple comparison procedure.

Table I. Seedling morphological attributes (and their standard errors) measured after 14 weeks in four hardening regimes ( $n=50$ ). Means within rows followed by different letters differ significantly (Fisher's protected LSD, $P \leq 0.05$ ).

\begin{tabular}{|c|c|c|c|c|c|}
\hline \multirow[t]{2}{*}{ Attribute } & \multicolumn{4}{|c|}{ Hardening regime } & \multirow{2}{*}{$\begin{array}{l}P \text { value from } \\
\text { ANOVA }\end{array}$} \\
\hline & $\begin{array}{l}\text { Outdoor } \\
\text { (OD) }\end{array}$ & $\begin{array}{c}\text { Natural daylengths } \\
+ \text { warm temperatures } \\
(\mathrm{NDW})\end{array}$ & $\begin{array}{l}\text { Natural daylengths } \\
+ \text { warm temperatures } \\
\text { + fertilizer (NDWF) }\end{array}$ & $\begin{array}{l}\text { Short daylengths } \\
\text { (SD) }\end{array}$ & \\
\hline \multirow{2}{*}{ Root collar diameter (mm) } & $1.64 \mathrm{ab}$ & $1.74 \mathrm{bc}$ & $1.80 \mathrm{c}$ & $1.57 \mathrm{a}$ & 0.003 \\
\hline & $(0.054)$ & $(0.050)$ & $(0.044)$ & $(0.037)$ & \\
\hline \multirow[t]{2}{*}{ Height $(\mathrm{cm})$} & $14.8 \mathrm{a}$ & $18.6 \mathrm{bc}$ & $18.9 \mathrm{c}$ & $17.2 \mathrm{~b}$ & $<0.001$ \\
\hline & $(0.46)$ & $(0.45)$ & $(0.58)$ & $(0.52)$ & \\
\hline \multirow[t]{2}{*}{ Shoot dry weight (g) } & $0.50 \mathrm{a}$ & $0.62 b$ & $0.57 \mathrm{a}$ & $0.51 \mathrm{a}$ & 0.032 \\
\hline & $(0.033)$ & $(0.035)$ & $(0.032)$ & $(0.030)$ & \\
\hline
\end{tabular}

seedlings had significantly more needle primordia in terminal buds than other treatments (Fig. 2 inset): NDWF seedlings had an average of 237 primordia, while NDW seedlings produced significantly more primordia than the OD regime (ANOVA $P$-value $<0.001)$.

\subsection{Index of injury}

In the first 4 weeks of treatment index of injury tended to be lowest in SD seedlings (Fig. 3a), although the differences were not always significant. The $-10^{\circ} \mathrm{C}$ index of injury fell to $10 \%$ or less for the first time after 9 weeks of hardening for SD and OD trees and after 10 and 12 weeks for NDWF and NDW seedlings, respectively (Fig. 3a). On weeks 11-13, NDW trees had significantly higher index of injury when exposed to $-17^{\circ} \mathrm{C}$ (Fig. 3b). The ANOVA $P$-values for freezing at $-10^{\circ} \mathrm{C}$ were not significant on weeks $2,4,5$ and 12 . For the other weekly $-10^{\circ} \mathrm{C}$ freezing tests the ANOVA $P$-values were at or below 0.005 , except for week 1 where it was 0.016 . When frozen to $-17^{\circ} \mathrm{C}$ the ANOVA $P$-values were 0.005 on week 8 , 0.002 on week $9,<0.001$ from weeks 10 through 13 and nonsignificant (0.561) on week 14 .

\subsection{Transpiration}

On weeks 4 and 8, transpiration was greatest in OD seedlings (ANOVA $P$-values of 0.014 and 0.002 , respectively) (Fig. 4). In contrast, on weeks 10 and 12, transpiration was lowest in OD seedlings (ANOVA $P$-values of 0.003 and 


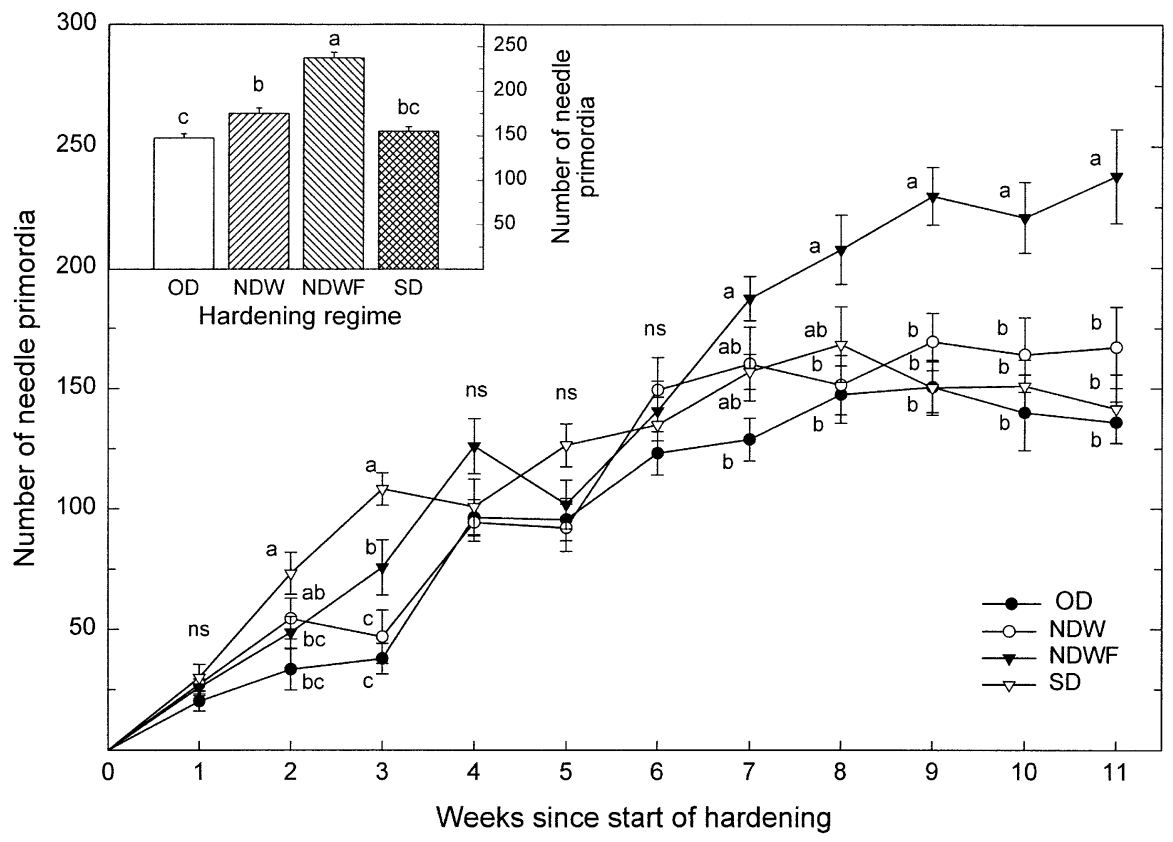

Figure 2. Needle primordia initiation over time in terminal buds of black spruce seedlings from four hardening regimes. Inset is the number of needle primordia in terminal buds (and standard errors bars) averaged for weeks 12 to $14(n=55$ to 60$)$. Means and standard error bars for each week in the main graph were calculated using from 13 to 30 buds (average $=20$ ). Within any week, symbols with differing letters are significantly different according to one way ANOVA of means and Fisher's protected LSD test $(P \leq 0.05)$ (weeks $2,3,5,6,10$ and 11$)$. For other weeks, significantly differing treatments were determined using the Kruskal-Wallis one way ANOVA on ranks and Dunn's method for all-pairwise multiple comparisons. For the comparison of the number of needle primordia in terminal buds averaged for weeks 12 to 14 ( $n=$ 55 to 60), bars with different letters differ significantly based on a Kruskal-Wallis one way ANOVA on ranks and Dunn's all-pairwise multiple comparison procedure $(P \leq 0.05)$.

0.013 , respectively). There were few differences in transpiration at any time among treatments hardened in the greenhouse. Transpiration on week 14 was between about $20 \%$ and $50 \%$ of the rates measured 4 weeks after hardening began.

\subsection{Shoot xylem pressure potential}

Shoot xylem pressure potential was usually most negative in OD seedlings (Figs. 5 and 6 and Tab. II). Following 11 weeks of hardening (November 3, Fig. 5a), at which point NDW, NDWF, and SD seedlings were still inside the greenhouse, minimum shoot xylem pressure potential of OD seedlings during the day was $-1.3 \mathrm{MPa}$, while the next most negative treatment was NDWF at just above $-1.0 \mathrm{MPa}$. On November 10, one week after trees from the greenhouse (NDW, NDWF and SD) were moved outside, OD seedlings still tended to have significantly more negative xylem pressure potentials (Fig. 5b, Tab. II). On November 16, the container growing medium was frozen throughout the day; predawn shoot xylem pressure potential was $-3.5 \mathrm{MPa}$ in the OD treatment (Tab. II) and reached a midday minimum below $-5.4 \mathrm{MPa}$ (Fig. 6a). On the same day, predawn xylem pressure potentials in NDW, NDWF, and SD seedlings ranged from about -2.9 to $-3.2 \mathrm{MPa}$ (Tab. II), while the range in average midday xylem pressure potentials was -3.5 to $-4.5 \mathrm{MPa}$. On November 23 (Week 14) xylem pressure potentials were usually significantly less negative in SD seedlings and in OD trees tended to be significantly lower (Fig. 6b and Tab. II).

\subsection{Root growth potential}

Root growth potential was higher in November in all hardening regimes than in mid-winter (December and January) (Fig. 7). Between January and February, RGP approximately doubled in all greenhouse-hardened treatments, but not in seedlings hardened outdoors. Though not in all cases significant, the RGP of SD seedlings was lowest of all treatments in November, December and January. In March, the RGP of seedlings from the greenhouse hardening regimes did not differ significantly, while significantly lower RGP was found at that time in OD seedlings. The $P$-values from one-way ANOVAs of monthly RGP were 0.220, < 0.001, 0.037, $<0.001$ and $<0.001$ respectively in November, December, January, February and March.

\section{DISCUSSION}

Black spruce seedlings significantly differed in desiccation resistance, cold hardiness, and root growth potential depending on the nutrition they received and the environment they were exposed to during hardening. After being moved outside at the beginning of August, OD seedlings were exposed to cooler temperatures and higher light intensities than those experienced by NDW, NDWF and SD seedlings during hardening in a greenhouse. Seedlings from the SD regime experienced the same temperatures and light intensities as 


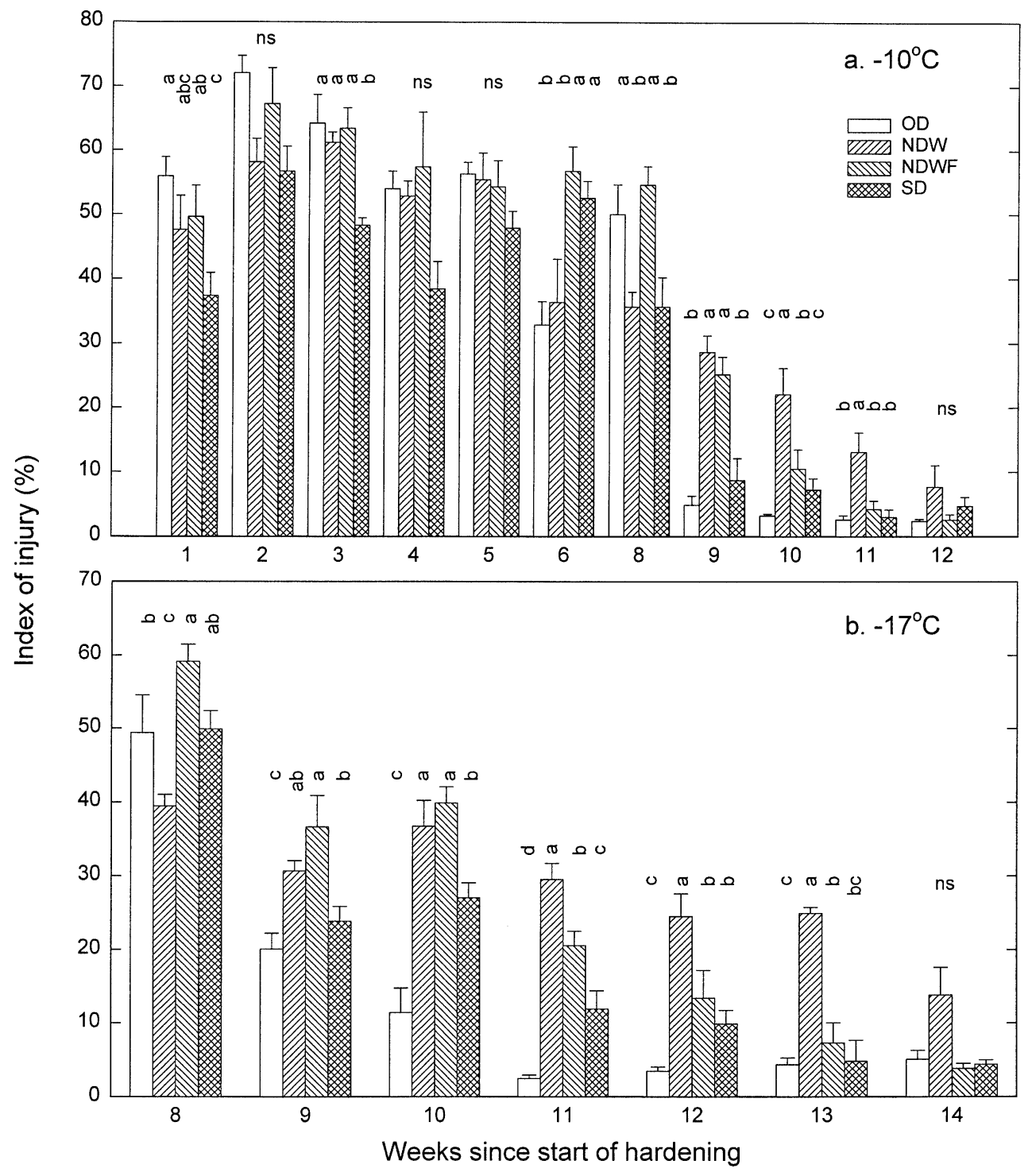

Figure 3. Index of injury (and standard error bars) of shoot tips from black spruce seedlings from four hardening regimes following freezing to a. $-10^{\circ} \mathrm{C}$ and b. $-17^{\circ} \mathrm{C}$. Within each week, bars with different letters differ significantly according to Fisher's protected LSD test $(P \leq 0.05)$. Each bar is the mean of 5 replicates of three shoot tips. No data is available for week 7 due to contamination of the samples with polyethylene glycol.

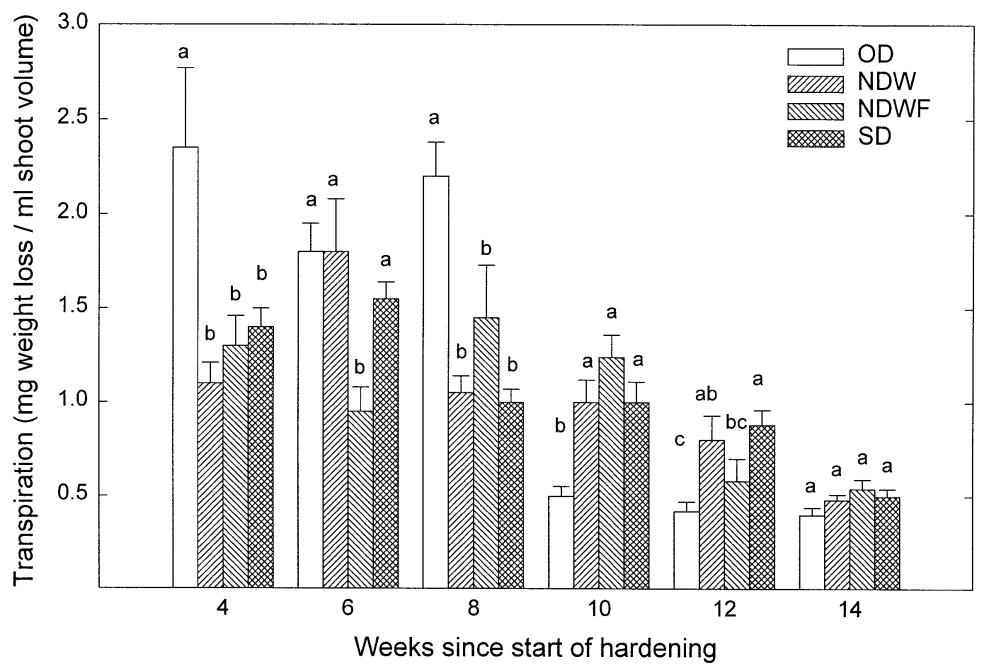

Figure 4. Transpiration (and standard error bars) of excised shoot tips of black spruce seedlings from four regimes during the course of hardening. Within each date, bars with different letters differ significantly according to Fisher's protected LSD test $(P \leq 0.05)$. Each bar is the mean of four replicates of three shoot tips. 


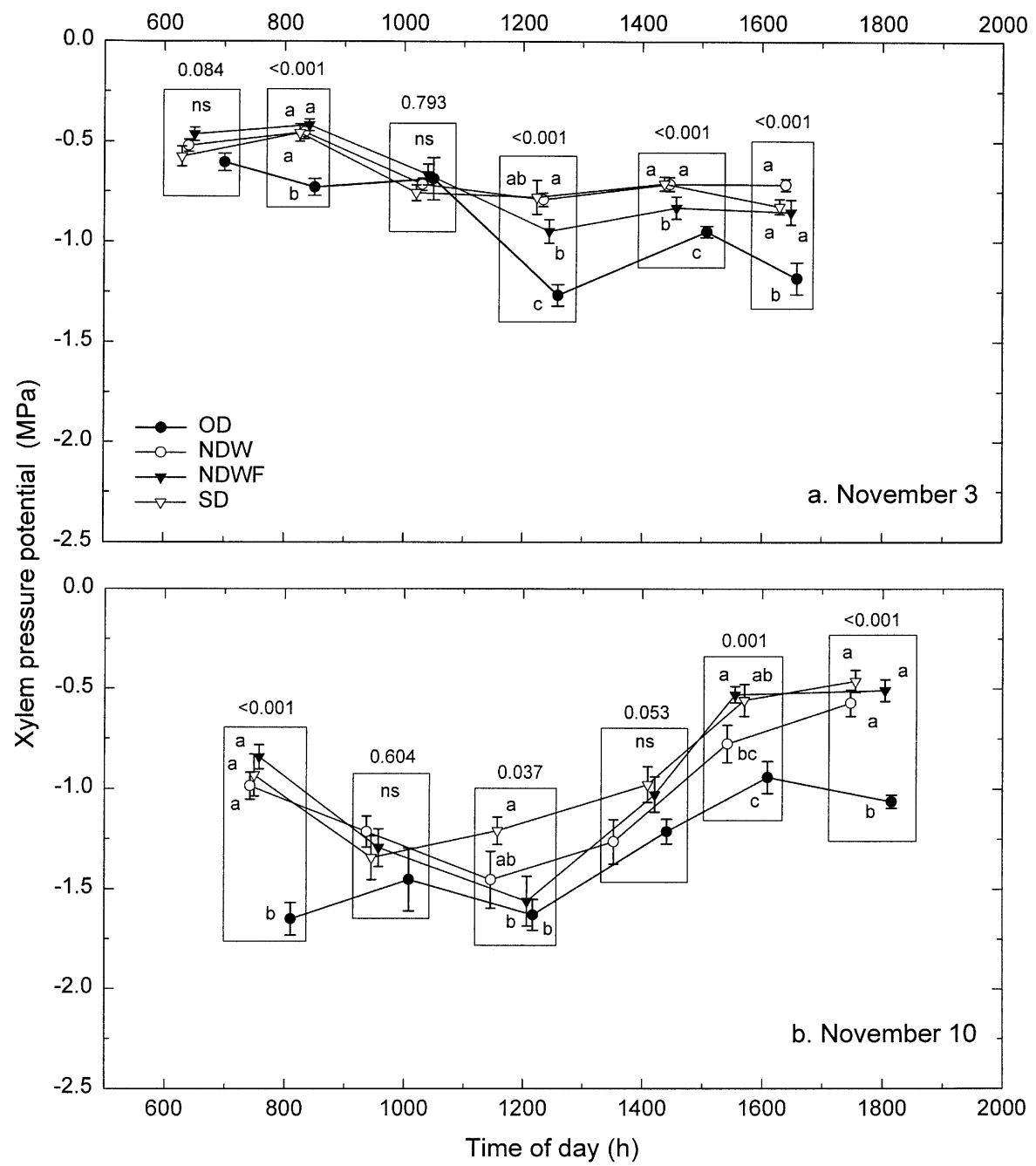

Figure 5. Shoot xylem pressure potential (and standard error bars) of black spruce seedlings from four hardening regimes on a. November 3 (top), 11 weeks after the start of hardening and b. November 10 (bottom), 12 weeks after the start of hardening. On each date, symbols with differing letters enclosed in boxes differ significantly according to Fisher's protected LSD test $(P \leq 0.05, n=10)$, or do not differ significantly (ns). Numbers above boxes are the $P$-values from one-way analysis of variance of the enclosed data points.

NDW and NDWF seedlings but a shorter daylength (8 h). Fertilizer was applied during hardening only to NDWF seedlings, which experienced the same temperatures and light intensities as NDW and SD seedlings and the same photoperiod as OD and NDW trees.

\subsection{Seedling morphology}

Shortened photoperiods in the SD regime were used only 4 of every 7 days, or about $55 \%$ of the time. The remainder of the time, seedlings were exposed to natural photoperiods that were themselves sufficiently short to induce budset. Although the intermittent nature of the treatment likely reduced its effect, photoperiod reduction in the SD treatment was additive to the dormancy-inducing stimulus of the naturally shortening daylengths. Short day treatment resulted in the initiation of terminal buds approximately one week faster than in other treatments.
The earlier initiation of terminal buds in SD seedlings provided a longer period of warmer temperatures in which to initiate needle primordia. However, short day treatment also resulted in smaller seedling diameter, and this was likely the reason fewer primordia formed compared with NDW and NDWF seedlings [8]. Although nutrient concentrations were not measured there were clear effects of fertilization. For example, significantly more needle primordia were formed in fertilized seedlings, which could either be because of the larger diameter of NDWF trees or perhaps an indirect effect of nutrition [30]. In contrast, Bigras et al. [4] found no effect of nutrition on needle primordia initiation in second-year black spruce seedlings, despite fertilized trees also having greater diameter. In the present trial, the lowest number of primordia were formed in terminal buds of OD seedlings, which is attributed to cold temperatures during bud development [12, 29]. In addition to reducing height growth and number of needle primordia, cold temperatures during hardening affected 


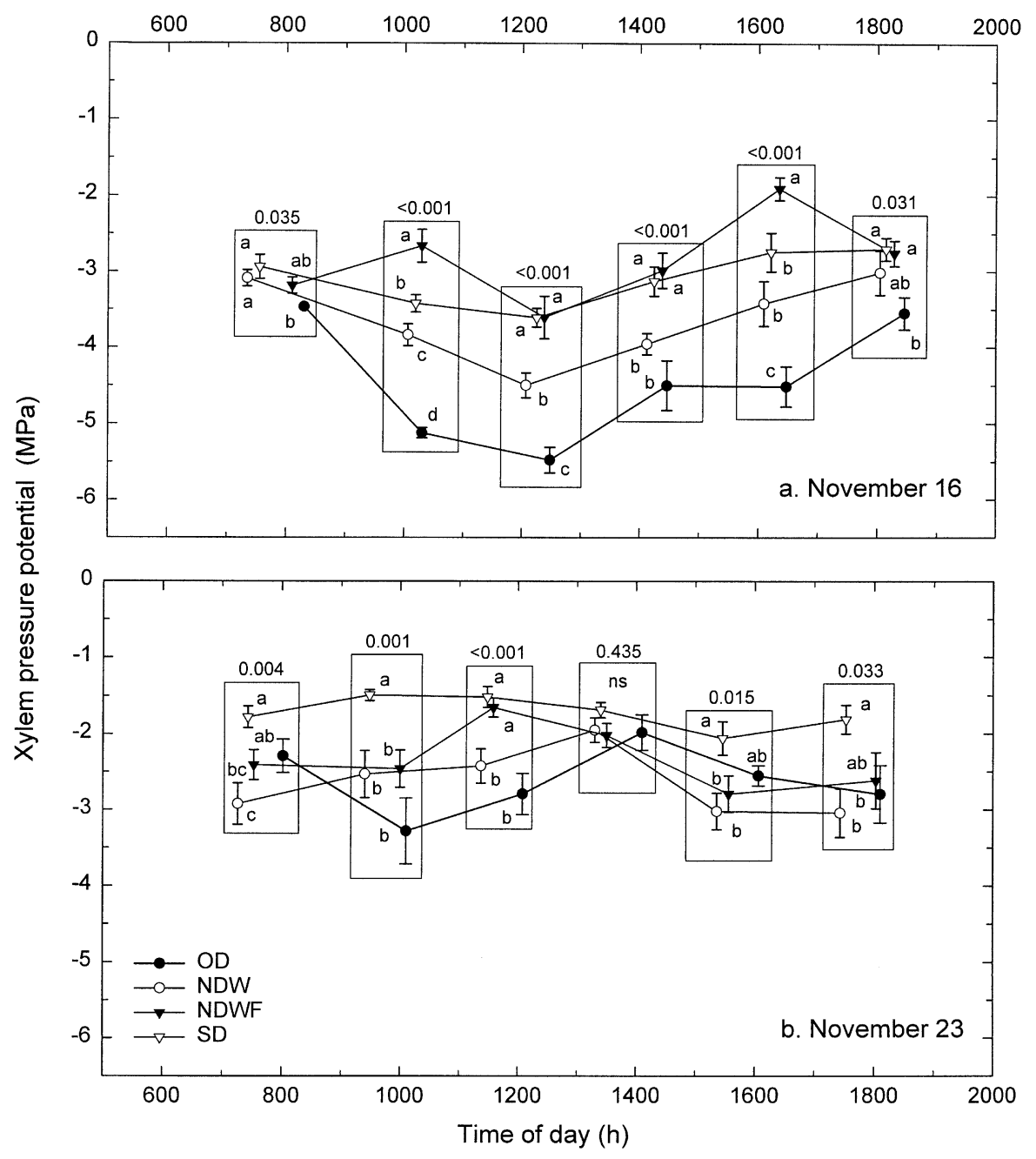

Figure 6. Shoot xylem pressure potential (and standard error bars) of black spruce seedlings from four hardening regimes on a. November 16 (top), 13 weeks after the start of hardening and b. November 23 (bottom), 14 weeks after the start of hardening. For data in the box centered on about $1015 \mathrm{~h}$ on November 16, symbols with differing letters differ significantly (Kruskal-Wallis one way ANOVA on ranks and StudentNewman-Keuls all-pairwise multiple comparison procedure). On all other times on each date, symbols with differing letters enclosed in boxes differ significantly according to Fisher's protected LSD test $(P \leq 0.05, n=10)$. Numbers above boxes are the $P$-values from one-way analysis of variance of the enclosed data points.

the ability of OD seedlings to control water loss, predisposing them to lower xylem pressure potentials.

\subsection{Desiccation resistance}

Seedlings experienced very low shoot xylem pressure potentials in November when temperatures were below freezing, which would restrict the supply of water from the container growing medium to shoots exposed to the air. At these times, seedlings hardened outdoors were most susceptible to dehydration, reaching xylem pressure potentials below $-5 \mathrm{MPa}$. At the end of November, SD seedlings were found to have the least negative xylem pressure potentials, although even these were as low as $-2 \mathrm{MPa}$. The lowest xylem pressure potentials observed in this trial are equivalent to those observed in Engelmann spruce (Picea engelmannii (Parry) Engelm.) krum- mholz growing at the timberline in southeastern Wyoming [22] and Utah [23]. Water potentials this low are sufficient to cause extensive cavitation in Norway spruce (Picea abies (L.) Karst.) $[10,27]$ and likely also in black spruce.

Winter desiccation in timberline conifers has been attributed to the slow but long-term loss of water through inadequately formed and/or abraded needle cuticles coupled with a restricted supply of moisture due to cold or frozen soil [22, 37]. The poorer ability of OD seedlings to control water loss in the first 8 weeks of hardening is shown by their greater transpiration rates compared with stock in the SD, NDW, and NDWF treatments. Greater water loss was previously found to be a feature of needles of nursery-grown seedlings that harden without a period of short days and warm temperatures prior to exposure to cool temperatures [38]. If cold temperature hardening is not preceded by a period of warm temperatures after 
Table II. Predawn shoot xylem pressure potentials (MPa) (and their standard errors) of black spruce seedlings from four hardening treatments during October and November $(n=10)$. Means within rows followed by the same letter do not differ significantly (Fisher's protected LSD, $P \leq 0.05)$.

\begin{tabular}{|c|c|c|c|c|c|}
\hline Date and week & $\begin{array}{l}\text { Outdoor } \\
\text { (OD) }\end{array}$ & $\begin{array}{l}\text { Natural daylengths }+ \text { warm } \\
\text { temperatures (NDW) }\end{array}$ & $\begin{array}{c}\text { Natural daylengths + warm } \\
\text { temperatures + fertilizer (NDWF) }\end{array}$ & $\begin{array}{l}\text { Short daylengths } \\
\text { (SD) }\end{array}$ & $\begin{array}{l}P \text { value from } \\
\text { ANOVA }\end{array}$ \\
\hline October 14 (week 8) & $\begin{array}{l}-0.339 \mathrm{a} \\
(0.0345)\end{array}$ & $\begin{array}{l}-0.665 b \\
(0.0433)\end{array}$ & $\begin{array}{l}-0.677 \mathrm{~b} \\
(0.0531)\end{array}$ & $\begin{array}{l}-0.583 b \\
(0.0452)\end{array}$ & $<0.001$ \\
\hline November 2 & $\begin{array}{c}-0.967 \mathrm{a} \\
(0.0640)\end{array}$ & $\begin{array}{l}-0.432 \mathrm{~b} \\
(0.0491)\end{array}$ & $\begin{array}{l}-0.470 \mathrm{~b} \\
(0.0564)\end{array}$ & $\begin{array}{l}-0.474 \mathrm{~b} \\
(0.0409)\end{array}$ & $<0.001$ \\
\hline $\begin{array}{l}\text { November } 3 \\
\text { (week 11) }\end{array}$ & $\begin{array}{c}-0.604 \mathrm{a} \\
(0.0441)\end{array}$ & $\begin{array}{l}-0.520 \mathrm{a} \\
(0.0307)\end{array}$ & $\begin{array}{l}-0.462 \mathrm{a} \\
(0.0338)\end{array}$ & $\begin{array}{l}-0.575 \mathrm{a} \\
(0.0503)\end{array}$ & 0.084 \\
\hline November 7 & $\begin{array}{l}-1.366 \mathrm{a} \\
(0.2074)\end{array}$ & $\begin{array}{l}-1.394 \mathrm{a} \\
(0.1572)\end{array}$ & $\begin{array}{l}-1.276 \mathrm{a} \\
(0.1451)\end{array}$ & $\begin{array}{l}-0.972 \mathrm{a} \\
(0.1511)\end{array}$ & 0.277 \\
\hline $\begin{array}{l}\text { November } 10 \\
\text { (week 12) }\end{array}$ & $\begin{array}{l}-1.649 \mathrm{a} \\
(0.0815)\end{array}$ & $\begin{array}{l}-0.985 b \\
(0.0666)\end{array}$ & $\begin{array}{l}-0.841 \mathrm{~b} \\
(0.0607)\end{array}$ & $\begin{array}{l}-0.932 b \\
(0.1039)\end{array}$ & $<0.001$ \\
\hline $\begin{array}{l}\text { November } 16 \\
\text { (week 13) }\end{array}$ & $\begin{array}{l}-3.466 \mathrm{a} \\
(0.1165)\end{array}$ & $\begin{array}{l}-3.089 \mathrm{~b} \\
(0.1084)\end{array}$ & $\begin{array}{r}-3.186 a b \\
(0.1078)\end{array}$ & $\begin{array}{l}-2.940 \mathrm{~b} \\
(0.1575)\end{array}$ & 0.035 \\
\hline $\begin{array}{l}\text { November } 23 \\
\text { (week 14) }\end{array}$ & $\begin{array}{l}-2.291 b c \\
(0.2198)\end{array}$ & $\begin{array}{l}-2.921 \mathrm{a} \\
(0.2723)\end{array}$ & $\begin{array}{r}-2.408 \mathrm{ab} \\
(0.1978)\end{array}$ & $\begin{array}{l}-1.777 \mathrm{c} \\
(0.1416)\end{array}$ & 0.004 \\
\hline
\end{tabular}

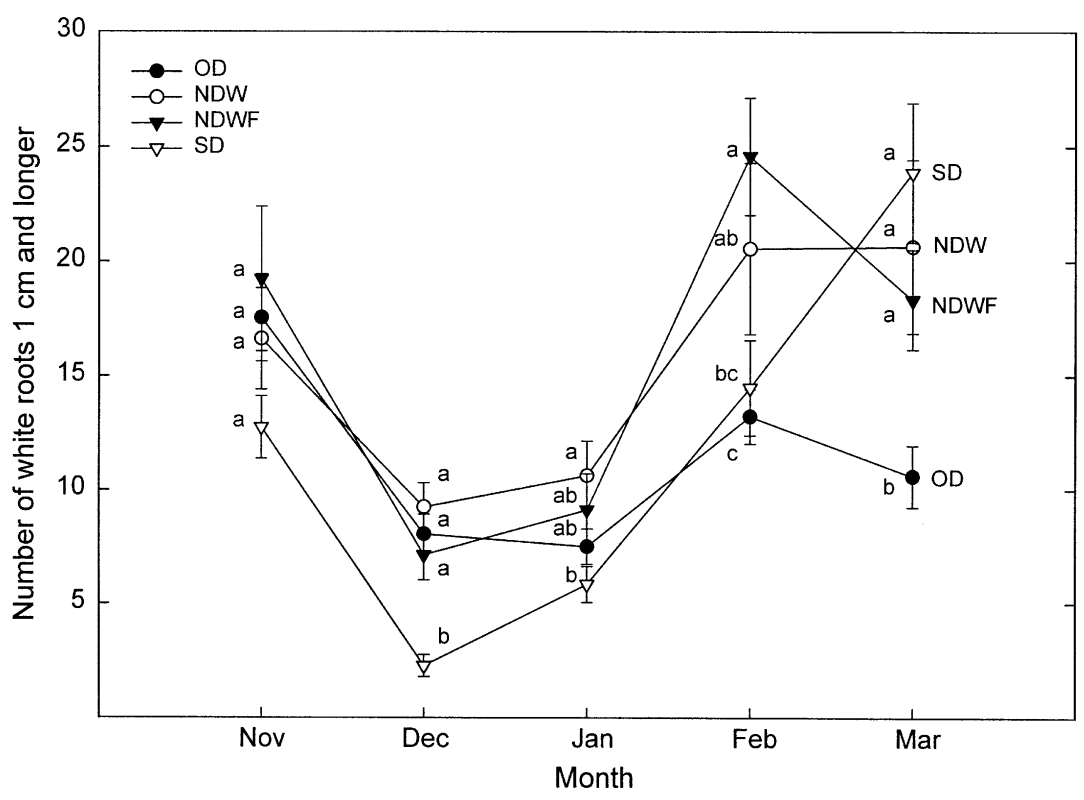

Figure 7. Root growth potential (and standard error bars) of black spruce seedlings from four hardening regimes during the winter. Symbols with different letters differ significantly in each month (Fisher's protected LSD, $P \leq 0.05, n=16$ to 50 ).

dormancy, the result is a thinner needle cuticle and poorly developed shoot periderm [17], similar to trees growing near the timberline [37]. After mid-October, OD seedlings had significantly lower shoot xylem pressure potentials but also tended to have lower rates of transpiration. Since shoots were not rehydrated prior to evaluating transpiration, the desiccated condition of OD seedlings was probably responsible for their reduced transpiration. The lower xylem pressure potentials experienced by OD seedlings may have increased their cold hardiness relative to other treatments. In addition to dehydra- tion caused by transpirational water loss from tissues, freezing dehydrates cells without affecting total tissue moisture content by drawing water to ice crystals forming in intercellular spaces $[16,21,32]$.

\subsection{Cold hardiness}

In the first 8 weeks of hardening there were no large differences between treatments in cold hardiness. There was, however, a trend towards greater cold hardiness in seedlings 
receiving short day treatment in the first 4 weeks of hardening. Short day treated seedlings also became hardy to $-10{ }^{\circ} \mathrm{C}$ sooner than NDW and NDWF seedlings, which could be attributed to a phenological advantage conferred by earlier growth cessation and bud initiation. More rapid hardening also occurred in OD compared to NDW and NDWF seedlings, and was likely due to the colder temperatures OD seedlings were exposed to outdoors [20]. It also may have been a response to desiccation [26], as desiccated tissues are more cold hardy than fully hydrated ones [28]. While seedlings exposed to colder temperatures during the early stages of hardening can cold harden more quickly, it has been shown elsewhere that premature exposure to cold temperatures can prevent the attainment of maximal cold hardiness $[12,36]$.

Black spruce shoots have been shown to have the capacity to harden to more than $-40{ }^{\circ} \mathrm{C}$ if exposed to dormancy inducing daylengths even without cold temperature exposure [11]. Therefore, hardening beyond $-10{ }^{\circ} \mathrm{C}$ in this trial at warm temperatures was expected. There was a large increase in cold hardiness on week 9 in all but the NDW treatment. This rapid hardening coincided with a slowing in the rates of needle primordia initiation. It has been shown that mitotic activity is elevated during rapid needle primordia initiation and that both mitotic activity and rates of needle primordia initiation are negatively correlated with shoot cold hardiness $[9,14]$. Since it was only NDW trees that did not experience a large increase in cold hardiness when needle primordia initiation ceased, it could be inferred that low levels of $\mathrm{N}, \mathrm{P}$ and/or $\mathrm{K}$ interfered with cold hardening, but that this could be compensated for by exposure to either cold temperatures or short days.

Reports of macronutrient fertilization effects on cold hardiness are contradictory $[5,15]$; they range from no effect [3] to increased cold hardiness $[4,7]$ to decreased cold hardiness with fertilization [24]. Fertilization that delays bud initiation would also delay cold hardening. To understand the effects of fertilization on cold hardening apart from such developmental differences, it is necessary to compare fertilized and non-fertilized seedlings that entered dormancy (initiated terminal buds) at the same time. In the current trial, fertilized (NDWF) and non-fertilized (NDW) seedlings, which were both exposed to warm temperatures and naturally declining daylengths, initiated terminal buds at the same time. However, the fertilized seedlings hardened more rapidly. In contrast, non-fertilized seedlings exposed to short days (SD) or to cooler temperatures outdoors (OD) were equally or more cold hardy than fertilized seedlings. Whether fertilizing SD and OD trees would have increased their cold hardiness is unknown.

Bigras et al. [4] observed that black spruce seedlings were more cold hardy at higher NPK fertilization levels (fertilization treatments in their trial being applied prior to bud initiation during the second growing season, but not during cold hardening). They found that trees were unable to harden at the lowest level of fertilization and that at an intermediate rate of fertilization an intermediate level of cold hardiness was achieved. In the present trial, non-fertilized seedlings developed cold hardiness more slowly than fertilized seedlings. In this experiment, differences in nutrient levels would have developed gradually after hardening began, while in Bigras et al. [4] seedlings already had significantly different nutrient levels at the start of hardening. In another trial [7] black spruce seedlings were fertilized with NPK at two rates, neither of which resulted in nutrient deficiency, and no differences in cold hardiness were observed. These results show that fertilization at moderate to high rates can have beneficial effects on cold hardening while nutrient deficiency can slow or prevent high levels of cold hardiness being achieved.

\subsection{Root growth potential}

Although differing in cold hardiness, fertilization did not result in differences in root growth potential compared to nonfertilized seedlings hardened at warm temperatures. Early in the winter, root growth potential was greater in seedlings hardened under natural (NDW, NDWF and OD regimes) as opposed to short daylengths. However, by March, root growth potential was greater in seedlings hardened under warm temperatures (NDW, NDWF, and SD regimes) compared with the cool-temperature OD regime. High levels of root growth potential are desirable for planting stock [6, 33]. These results show that root growth potential can be varied using environmental treatments during hardening. Such information could potentially be used to increase root growth potential and thereby improve the survival and growth of seedlings used in reforestation.

\section{CONCLUSION}

The results of this trial improve the understanding of how seedlings interact with their environment to develop resistance to winter stresses. This information is relevant to understanding the survival of seedlings in natural environments as well as in nurseries. However, nursery stock hardening should be done both to avoid damage during the winter and to produce seedlings with desirable characteristics for planting. High root growth potential at the time of planting is advantageous and in this trial was highest in the spring in seedlings hardened at warmer temperatures the preceding autumn.

Applying fertilizer in conjunction with warm temperatures after terminal buds were initiated produced seedlings with high root growth potential, shoots that were more cold hardy and less susceptible to winter desiccation, and terminal buds containing more needle primordia, all of which are desirable traits for trees that are to be planted. Seedlings hardened using short days and warm temperatures became cold hardy sooner than those hardened under otherwise comparable conditions at naturally shortening daylengths, however, the terminal buds of short-day-treated seedlings were smaller. Using a daylength that was bud inductive but closer to the critical daylength for bud initiation may have provided the same advantage in speed of cold hardening without reducing bud size. Based on these findings, it would be expected that a combination of short days, warm temperatures, and fertilizer during the initial stages of hardening, followed by progressively declining temperatures, would provide close to an optimum regime for hardening black spruce seedlings for overwintering. 


\section{REFERENCES}

[1] Aitken S.N., Hannerz M., Genecology and gene resource management strategies for conifer cold hardiness, in: Bigras F.J., Colombo, S.J. (Eds.), Conifer Cold Hardiness, Kluwer Academic Press, Dordrecht, The Netherlands, 2001, pp. 23-53.

[2] Bannister P., Neuner G., Frost resistance and the distribution of conifers, in: Bigras F.J., Colombo, S.J. (Eds.), Conifer Cold Hardiness, Kluwer Academic Press, Dordrecht, The Netherlands, 2001, pp. 3-21.

[3] Bigras F.J., Rioux J.-A., Paquin R., Therrien H.-P., Influence de la prolongation de la fertilization à l'automne sur la tolérance au gel et sur la croissance printanière du Juniperus chinensis 'Pfitzerana' cultivé en contenants, Phytoprotection 70 (1989) 75-84.

[4] Bigras F.J., Gonzales A., D’Aoust A.L., Hébert C., Frost hardiness, bud phenology and growth of containerized Picea mariana seedlings grown at three nitrogen levels and three temperature regimes, New For. 12 (1996) 243-259.

[5] Bigras F.J., Ryyppö A., Lindström A., Stattin E., Cold acclimation and deacclimation of shoots and roots of conifer seedlings, in: Bigras F.J., Colombo S.J. (Eds.), Conifer Cold Hardiness, Kluwer Academic Press, Dordrecht, The Netherlands, 2001, pp. 57-88.

[6] Burdett A.N., Simpson D.G., Thompson C.F., Root development and plantation establishment success, Plant Soil 71 (1983) 103-110.

[7] Calmé S., Margolis H.A., Bigras F.J., Influence of cultural practices on the relationship between frost tolerance and water content of containerized black spruce, white spruce, and jack pine seedlings, Can. J. For. Res. 23 (1993) 503-511.

[8] Cannell M.G.R., Analysis of shoot apical growth of Picea sitchensis seedlings, Ann. Bot. 42 (1978) 1291-1303.

[9] Cannell M.G.R., Tabbush P.M., Deans J.D., Hollingsworth M.K., Sheppard L.J., Philipson J.J., Murray M.B., Sitka spruce and Douglas fir seedlings in the nursery and in cold storage: Root growth potential, carbohydrate content, dormancy, frost hardiness and mitotic index, Forestry 63 (1990) 9-27.

[10] Cochard H., Vulnerability of several conifers to air embolism, Tree Physiol. 11 (1992) 73-83.

[11] Colombo S.J., Bud dormancy status, frost hardiness, shoot moisture content, and readiness of black spruce container seedlings for frozen storage, J. Amer. Soc. Hort. Sci 115 (1990) 302-307.

[12] Colombo S.J., Frost hardening spruce container stock for overwintering in Ontario, New Forests 13 (1997) 449-467.

[13] Colombo S.J., Glerum C., Winter injury to shoots as it affects root activity in black spruce seedlings, Can. J. For. Res. 14 (1984) 31-32.

[14] Colombo S.J., Glerum C., Webb D.P., Winter hardening in firstyear black spruce (Picea mariana) seedlings, Physiol. Plant. 76 (1989) 1-9.

[15] Colombo S.J., Menzies M.I., O'Reilly C., Influence of nursery cultural practices on cold hardiness of coniferous forest tree seedlings, in: Bigras F.J., Colombo S.J. (Eds.), Conifer Cold Hardiness, Kluwer Academic Press, Dordrecht, The Netherlands, 2001, pp. 223-252.

[16] Dereuddre J., Effets de divers types de refroidissements sur la teneur en eau et sur la résistance au gel des bourgeons de rameaux d'Épicéa en vie ralentie, Physiol. Veg. 16 (1978) 469-489.

[17] Evans L.S., Besemeyer P.T., Initial twig injury to high elevation Picea rubens in eastern North America caused by inadequate periderm formation, Amer. J. Bot. 75 (1988) 1378-1386.

[18] Flint H.L., Boyce B.R., Beattie D.J., Index of Injury - A useful expression of freezing injury to plant tissues as determined by the electrolytic method, Can. J. Plant Sci. 47 (1967) 229-230.
[19] Glerum C., Frost hardiness of forest trees, in: Cannell M.G.R., Last F.T., (Eds.),Tree Physiology and Yield Improvement, Chap. 23, Academic Press, London, 1976, pp. 403-420.

[20] Greer D.H., Warrington I.J., Effect of photoperiod, night temperature, and frost incidence on development of frost hardiness in Pinus radiata, Aust. J. Plant Physiol. 9 (1982) 333-342.

[21] Grossnickle S.C., Relationship between freezing tolerance and shoot water relations of western red cedar, Tree Physiol. 11 (1992) $229-240$.

[22] Hadley J.L., Smith W.K., Wind effects on needles of timberline conifers: seasonal influence on mortality, Ecology 67 (1986) 12-19.

[23] Hansen D.H., Klikoff L.G., Water stress in krummholz, Wasatch Mountains, Utah, Bot. Gaz. 133 (1972) 392-394.

[24] Hellergren J., Frost hardiness in Pinus silvestris seedlings in response to fertilization, Physiol. Plant. 52 (1981) 297-301.

[25] Krasowski M.J., Simpson D.G., Frost-related problems in the establishment of coniferous forests, in: Bigras F.J., Colombo S.J. (Eds.), Conifer Cold Hardiness, Kluwer Academic Press, Dordrecht, The Netherlands, 2001, pp. 253-285.

[26] Levitt J., Response of Plants to Environmental Stresses, Vol. I. Chilling, Freezing and High Temperature Stress, 2nd ed., Academic Press, Toronto, Canada, 1980.

[27] Lu P., Biron P., Granier A., Cochard H., Water relations of adult Norway spruce (Picea abies (L) Karst) under soil drought in the Vosges mountains: whole tree hydraulic conductance, xylem embolism and water loss regulation, Ann Sci. For. 53 (1996) 113-121.

[28] Parsons L.R., Li P.H., Changes in frost hardiness of stem cortical tissues of Cornus stolonifera Michx. after recovery from water stress, Plant Physiol. 64 (1979) 351-353.

[29] Pollard D.F.W., Logan K.T., The effects of light intensity, photoperiod, soil moisture potential, and temperature on bud morphogenesis in Picea seedlings, Can. J. For. Res. 7 (1977) 415-421.

[30] Pollard D.F.W., Logan K.T., The response of bud morphogenesis in black spruce and white spruce provenances to environmental variables, Can. J. For. Res. 9 (1979) 211-217.

[31] Repo T., Zhang G., Ryyppö A., Rikala R., Vuorinen M., The relation between growth cessation and frost hardening in Scots pines of different origins, Trees 14 (2000) 456-464.

[32] Sakai A., Extraorgan freezing of primordial shoots of winter buds of conifer, in: Li P.H., Sakai A. (Eds.), Plant Cold Hardiness and Freezing Stress, Vol. 2, Academic Press, New York, 1982, pp. 199-209.

[33] Simpson D.G., Ritchie G.A., Does RGP predict field performance? A debate, New For. 13 (1997) 253-277.

[34] Sutinen M.-L., Arora R., Wisniewski M., Ashworth E., Strimbeck R., Palta J., Mechanisms of frost survival and freeze-damage in nature, in: Bigras F.J., Colombo S.J. (Eds.), Conifer Cold Hardiness, Kluwer Academic Press, Dordrecht, The Netherlands, 2001, pp. 89-120.

[35] Templeton C.W.G., Odlum K.D., Colombo S.J., How to identify bud initiation and count needle primordia in first-year spruce seedlings, For. Chron. 69 (1993) 431-437.

[36] Timmis R., Worall J., Environmental control of cold acclimation in Douglas fir during germination, active growth and rest, Can. J. For. Res. 5 (1975) 464-477.

[37] Tranquillini W., Physiological Ecology of the Alpine Timberline, Ecological Studies 31, Springer-Verlag, New York, 1979.

[38] Vanhinsburg N., Colombo S.J., Effect of temperature on needle anatomy and transpiration of Picea mariana (Mill.) B.S.P. after bud initiation, Can. J. For. Res. 20 (1990) 598-601. 